\title{
Tożsamość a nowoczesność
}

\author{
Recenzja: \\ Jacek Dobrowolski. Wzlot i upadek człowieka nowoczesnego. \\ Warszawa: PWN, 2015, ss. 134
}

\section{Kamil Szymański}

https://orcid.org/0000-0002-9699-0541

Człowiek rozwija się biologicznie od milionów lat. Od tysięcy lat wykorzystuje swą zdolność do przekształcania świata za pomocą narzędzi, tworząc i rozwijając kulturę do poziomu, który znamy obecnie. Ludzkie zdolności stale wzrastają; przykładem jest rozwój robotyzacji, cyfryzacji, podróże kosmiczne, programowanie sztucznej inteligencji. Mimo, że człowiek dzięki nauce wie coraz więcej o świecie, to jednak pewien problem do dnia dzisiejszego wciąż pozostaje nierozwiązany - mianowicie pytanie o to, kim jest sam człowiek? Od tysięcy lat wielu filozofów próbowało sformułować odpowiedź na to filozoficzno-antropologiczne pytanie. Warto przywołać anegdotę, wedle której Platon, próbując definiować człowieka jako „zwierzę dwunożne, nieopierzone”, spotkał się z dość osobliwą krytyką. Diogenes z Synopy, usłyszawszy tę definicję, przyniósł Platonowi oskubanego, żywego kurczaka, mówiąc: „Oto człowiek Platona”.

Różni badacze starali się „zamknąć” człowieka w określonych ramach przywar lub cech, które odnajdują właśnie w homo. Johan Huizinga pisał o homo ludens ${ }^{1}$ - człowieku zabawy, który całe swoje życie jak i twórczą aktywność traktuje

KAMIL SZYMAŃSKI, doktorant nauk o poznaniu i komunikacji społecznej na Wydziale Filozofii i Socjologii UMCS w Lublinie, doktorant filozofii na Wydziale Filozofii KUL; adres do korespondencji: Instytut Filozofii UMCS, Pl. M. Curie-Skłodowskiej 4, 20-031, Lublin; e-mail: szym.kamil@gmail.com 
jako pewną grę. Hannah Arendt ${ }^{2}$ z kolei pisała o homo faber - człowieku działającym, zmieniającym i przekształcającym zarówno siebie, jak i swoje otoczenie (nie tylko w wymiarze technicznym, ale i społecznym oraz politycznym). Stefan Symotiuk określał człowieka mianem homo inquietus - jako człowieka niespokojnego, twórczego, pełnego nadmiaru energii i mocy. Natomiast Yuval Noah Harari uznaje człowieka za homo deus . Możliwości oferowane przez naukę i technikę mają dać człowiekowi „boskie” możliwości przekształcania świata, jak i samego siebie. Harari nawiązuje wprost do założeń transhumanizmu, który zakłada nadchodzący „skok” ewolucyjny człowieka ${ }^{4}$.

Choć w nauce formułowano wiele odpowiedzi, do tej pory żadna z nich nie wydaje się tą „najbardziej właściwą”. Pytanie więc wciąż pozostaje aktualne i czeka na „właściwą" odpowiedź. I właśnie do tego pytania nawiązuje Jacek Dobrowolski w monografii zatytułowanej Wzlot i upadek człowieka nowoczesnego. Książka składa się z 11 rozdziałów, które mieszczą się na 133 stronach. Zawiera także indeks osób i postaci literackich. Rozdziały zatytułowane są kolejno:

1. Wstęp. Kto, kogo, po co i jak?

2. Podmiot pomiędzy skrajnościami

3. Geneza: oszustwo sokratejsko-platońskie, czyli ta niewiarygodna potrzeba nieśmiertelności

4. Człowiek nowoczesny. Przypadki Robinsona

5. Naukowe podstawy człowieka nowoczesnego

6. Ewolucja człowieka nowoczesnego. Wąsy Nietzschego. Najlepiej przystosowany i człowiek bez właściwości. Cztery filary człowieczeństwa

7. Ewolucjonizm i zoodycea. Zwierzęcość człowieka nowoczesnego

8. Nowoczesność jako fałszywa świadomość

9. Technika i umysł. Bóg-maszyna. Jednostka wobec „Facebooka”

10. To, co powraca

11. Śmierć śmierci i człowiek późnej nowoczesności

${ }^{1}$ Johann Huizinga, Homo ludens: zabawa jako źródło kultury, tłum. Maria Kurecka i Witold Wirpsza (Warszawa: Wydawnictwo Aletheia, 2007).

${ }^{2}$ Hannah Arendt, Kondycja ludzka, tłum. Anna Łagodzka (Warszawa: Wydawnictwo „Aletheia”, 2010).

${ }^{3}$ Yuval N. Harari, Homo Deus: a brief history of tomorrow (New York: Harper Perennial, 2018).

${ }^{4}$ Max More i Natasha Vita-More (red.), The Transhumanist Reader: Classical and Contemporary Essays on the Science, Technology, and Philosophy of the Human Future (Chichester: John Wiley \& Sons, 2013). 
Warto wspomnieć, że praca została wyróżniona w II edycji Konkursu o Nagrodę im. Barbary Skargi ogłoszonego w 2013 roku przez Fundację na Rzecz Myślenia i rozstrzygniętego w roku 2014. Pytanie konkursowe, które sformułowali organizatorzy, brzmiało: Czy nauka i technika potrafią sprostać starożytnemu wezwaniu: Poznaj samego siebie?

Autor już na wstępie odpowiada negatywnie na tak postawione pytanie. Po pierwsze, zwraca uwagę, że poznać samego siebie może tylko podmiot poznający, którymi nie są ani nauka, ani technika. Po drugie - można analizować tę kwestię z perspektywy różnych podmiotów poznających siebie z odmiennych perspektyw. Właśnie pytanie o tożsamość, a w szczególności o tożsamość człowieka nowożytnego stanowi centrum rozważań Dobrowolskiego, który pragnie udzielić odpowiedzi, uwzględniając możliwości tzw. „naukowo-technologiczne”. Dzieło to nasuwa pewne skojarzenia z Rozprawą o naukach i sztukach Jeana-Jacquesa Rousseau $^{5}$, i to nie $\mathrm{z}$ tego względu, że oba dzieła powstały na konkurs filozoficzny, ale również z racji, że analizy w ich zawarte przekształcają się w krytykę kondycji ludzkiej oraz wpływu nauki i techniki na świadomość człowieka i jego pojmowanie świata.

Dobrowolski uważa, że starożytna maksyma „poznaj samego siebie”, która zakładała, że dzięki temu poznaniu człowiek jest w stanie nad samym sobą zapanować, co miało prowadzić do suwerenności, samodzielności czy samowładztwa - „skompromitowała się”6. Dowodem na tę kompromitację są tragiczne doświadczenia XX wieku, które świadczą, wedle autora, że człowiek nie korzysta z rozumu, lub korzysta $z$ niego $w$ ograniczonych sytuacjach ${ }^{7}$. Skutkiem tego „[... można chyba autorytatywnie przyjąć, że hasło ani nie spełniło swoich obietnic, ani też, najwyraźniej, nie trafia ono w samo jądro powszechnego ludzkiego zainteresowania i troski, więc jest to hasło przynajmniej po części oszustwem [...] jest ono złudzeniem, samo oszustwem [...]”'. Taka negatywna ocena wynika stąd, że według autora człowiek posiadający rozum nie ma w zwyczaju z niego korzystać, a jeżeli już to robi, to w ograniczony sposób. Innym argumentem na rzecz takiej oceny

\footnotetext{
${ }^{5}$ Jean-Jacques Rousseau, „Rozprawa o naukach i sztukach”, w: tenże, Trzy rozprawy z filozofii społecznej, tłum. Henryk Elzenberg (Warszawa: Państwowe Wydawnictwo Naukowe, 1956), 3-46.

${ }^{6}$ Jacek Dobrowolski, Wzlot i upadek człowieka nowoczesnego (Warszawa: Wydawnictwo Naukowe PWN, 2015), 14.

${ }^{7}$ Tamże, 15.

${ }^{8}$ Tamże.
} 
miałaby być zanikająca na poziomie globalnym westernizacja oraz kryzys „imperium cywilizacji europejskiej"', choć autor nie wyjaśnia, na czym ten kryzys miałby polegać.

Dobrowolski skupia się początkowo na wyjaśnieniu znaczenia i genezy tej kwestii. Podkreśla jej starożytne pochodzenie - już Sokrates doradzał Alkibiadesowi, że drogą do dobrych rządów jest właśnie poznanie siebie ${ }^{10}$. Uważa jednak, że starożytni, formułując to pytanie, tak naprawdę zwodzili swoich interlokutorów tym, że faktycznie można na nie w jakiś sposób odpowiedzieć. Autor zauważa, że choć już długo, jako ludzie, poszukujemy na nie odpowiedzi, to nie udało nam się dojść przez tyle wieków do żadnego konsensusu. Dlatego zastanawia się, czy w ogóle można odpowiedzieć na to pytanie ${ }^{11}$. Osobliwe jest również, że Sokratesa uznaje za „oszusta”, który dzięki swym metodom zamiast prowadzić interlokutora do poznania „samego siebie”, prowadził tak naprawdę do uznania za prawdę tego, co o człowieku wie sam Sokrates ${ }^{12}$. A prawdą miałoby być uznanie nieśmiertelności duszy oraz tego, co boskie - idei Platońskich. Sokrates miał jednak naruszyć przy tym tożsamość (czy też wyjątkowość) bogów, przenosząc pewne ich cechy, takie jak indywidualność czy wyjątkowość na człowieka (wcześniej mu nieprzypisywane). Wątek ten kontynuowany miał być przez kolejnych filozofów w myśli Zachodu, takich jak Kartezjusz, Kant, Hegel. Choć nauka, według autora, odgrywała istotne znaczenie w procesie indywidualizacji człowieka, prowadząc bezpośrednio do naturalizmu, to jednak, według autora, „naturalizm rozpuszcza jednostkowość, odbiera jej jakościową niepowtarzalność”13. Okazuje się, że zarówno idealistyczna antropologia teistyczna, jak i antropologia naturalistyczna nie udzieliła ostatecznie odpowiedzi na postawione pytanie. „Ostatecznie człowiek nie jest ani tylko Bogiem, ani tylko zwierzęciem, ani maszyną, ani egzemplarzem gatunku - jest bowiem wszystkim tym i zarazem czymś więcej”14.

Autor, krytyczny wobec prób budowy narracji o tożsamości człowieka, podkreśla jej złożoność, która uniemożliwia jednocześnie sformułowanie prostych

\footnotetext{
9 Tamże, 18.

10 Tamże, 23.

11 Tamże, 25.

12 Tamże, 26.

13 Tamże, 33.

14 Tamże, 35.
} 
odpowiedzi. Zwraca również uwagę, że technika, która doprowadziła do powstania teatrów, książek, sztuki, Internetu, filmów itd., również ma znaczący wpływ na poznanie samego siebie. Człowiek, poprzez swoją działalności i kreowany świat, może w nim dostrzec odbicie samego siebie, a co za tym idzie, po części również samego siebie poznać. Hasło poznania samego siebie, czyli troska o indywidualność konstytuuje w szczególności człowieka zachodniego ${ }^{15}$. O ile człowiek starożytny podlegał losowi i przeznaczeniu, to człowiek nowoczesny stał się już „panem własnego losu”, co niejako może prowadzić do dezaktualizacji pytania o tożsamość. W czasach wolności, kiedy człowiek może wybrać nie tylko zawód, miejsce zamieszkania ale również płeć kulturową, na pytanie „kim jestem?” można odpowiedzieć - „kim zechcę”. Dorowolski trafnie zwraca uwagę: „Jeśli zatem starożytne "poznaj samego siebie« jest w istocie moralizującym napomnieniem o istnieniu »granicy«, »miary«, o podporzadkowaniu człowieka siłom wyższym, to nowoczesne »poznaj samego siebie« jest raczej zachęta do zgłębiania wewnętrznej i gatunkowej nieskończoności, nieograniczoności jednostki i ludzkości [...]"16. Właśnie to trafne spostrzeżenie poddaje w wątpliwość stawianie obecnie tego typu pytań.

Dobrowolski zwraca uwagę na to, że skok naukowo-techniczny pozwolił na wyłonienie się właśnie podmiotowości wczesnonowoczesnej. Dodatkowo, przewrót kopernikański „wytrącił człowieka z przytulnego miejsca pośrodku stworzenia"17. Badania Newtona i Darwina wywarły wpływ na świadomość ludzką oraz jego tożsamość. Zdaniem autora, stopniowy wzrost znaczenia nauki prowadził do „umaterialnienia” człowieka, negując jego sferę duchową, która nie mogła być zbadana czy zmierzona, a więc i poznana. Dobrowolski wskazuje na stopniową dominację „witalizmu ewolucyjno-nietzscheańskiego jako jednej z form radykalnego materializmu"18.

Konkluzją rozważań jest podkreślenie, że XIX wiek był stuleciem śmierci Boga, XX wiek śmierci człowieka, a XXI ma być stuleciem „śmierci śmierci”"19. Śmierć, wedle Dobrowolskiego, dotyczy w tym wypadku zwrotu antropologicznego jako sformułowania ostatecznej odpowiedzi na pytanie, kim jest człowiek.

\footnotetext{
15 Tamże, 37.

16 Tamże, 41.

17 Tamże, 52.

18 Tamże, 87.

19 Tamże, 119.
} 
Dodatkowo, pisze on w dość pesymistycznym tonie: „któż w naszych czasach chciałby stawiać człowiekowi »wielkie zadania«, gdy dostatecznie trudne wydają się kwestie przetrwania jego cywilizacji?”20. Oznacza to, że według Dobrowolskiego nauka i technika nie prowadzą w ostateczności do odpowiedzi na to fundamentalne pytanie (a być może, nie dadzą odpowiedzi na żadne $\mathrm{z}$ fundamentalnych pytań). Prowadzą one jednak do „gwałtownych” przekształceń świata, wywołując wiele istotnych problemów, z którymi coraz gorzej sobie radzimy. Nauka i technika powinny prowadzić do tego, że człowiek będzie siebie coraz lepiej rozumiał; mimo stosunkowo większej wiedzy o świecie, w porównaniu z tą, którą posiadali starożytni, tak naprawdę człowiek wie o sobie tyle, co wiedziano kiedyś.

Warto zwrócić uwagę na styl pisarski autora; jest on dość luźny, nie posiada charakteru typowo akademickiego. Znajdziemy tu wiele zwrotów publicystycznych, tak jak: „A może nam tu coś wciskają?” [w sensie - problem poznania K. Sz. $]^{21}$, „mistrz PR Platon”22 czy „indywidualna egzystencja przekształca się w fitness”23. Tego typu język nie jest jednak wadą, gdyż „uwspółcześnia” formę przekazu, przez co odbiór książki jest łatwiejszy, przy całej powadze stawianego przez autora problemu. Dzięki tym zabiegom tekst nie traci, a zyskuje. Mimo lekkości języka, jest on w dalszym ciągu nasycony filozoficznymi wątkami.

Wzlot i upadek człowieka nowoczesnego to dość interesującą lekturą, która pokazuje, że wielkie pytania filozofii mogą być wciąż odkrywane, a próby udzielenia na nie odpowiedzi są ściśle skorelowane z czasami, w których przychodzi nam na nie odpowiadać.

\section{Bibliografia}

Arendt, Hannah. Kondycja ludzka. Tłum. Anna Łagodzka. Warszawa: Wydawnictwo „Aletheia”, 2010.

Dobrowolski, Jacek. Wzlot i upadek człowieka nowoczesnego. Warszawa: Wydawnictwo Naukowe PWN, 2015.

\footnotetext{
${ }^{20}$ Tamże, 120.

${ }^{21}$ Tamże, 25.

22 Tamże, 28.

${ }^{23}$ Tamże, 65.
} 
Harari, Yuval N. Homo Deus: a brief history of tomorrow. New York: Harper Perennial, 2018.

Huizinga, Johann. Homo ludens: zabawa jako źródło kultury. Tłum. Maria Kurecka i Witold Wirpsza. Warszawa: Wydawnictwo Aletheia, 2007.

The Transhumanist Reader: Classical and Contemporary Essays on the Science, Technology, and Philosophy of the Human Future, red. Max More i Natasha Vita-More. Chichester: John Wiley \& Sons, 2013.

Rousseau, Jean-Jacques. „Rozprawa o naukach i sztukach”. W: Jean-Jacques Rousseau, Trzy rozprawy z filozofii społecznej, tłum. Henryk Elzenberg, 3-46. Warszawa: Państwowe Wydawnictwo Naukowe, 1956.

Information about Author:

KAMIL SZYMAŃSKI, PhD student in cognitive science and social communication at the Faculty of Philosophy and Sociology, UMCS, Lublin, PhD student in Philosophy at the Faculty of Philosophy, KUL, Lublin; address for correspondence: Pl. Marii Curie-Skłodowskiej 4, PL 20-031 Lublin; e-mail: szym.kamil@gmail.com 